\title{
Seasonality of Freeze Tolerance in a Subarctic Population of the Wood Frog, Rana sylvatica
}

\author{
Jon P. Costanzo, M. Clara F. do Amaral, Andrew J. Rosendale, and Richard E. Lee \\ Department of Zoology, Miami University, Oxford, OH 45056, USA \\ Correspondence should be addressed to Jon P. Costanzo; costanjp@miamioh.edu
}

Received 18 December 2013; Accepted 20 February 2014; Published 24 March 2014

Academic Editor: Hynek Burda

Copyright (C) 2014 Jon P. Costanzo et al. This is an open access article distributed under the Creative Commons Attribution License, which permits unrestricted use, distribution, and reproduction in any medium, provided the original work is properly cited.

\begin{abstract}
We compared physiological characteristics and responses to experimental freezing and thawing in winter and spring samples of the wood frog, Rana sylvatica, indigenous to Interior Alaska, USA. Whereas winter frogs can survive freezing at temperatures at least as low as $-16^{\circ} \mathrm{C}$, the lower limit of tolerance for spring frogs was between $-2.5^{\circ} \mathrm{C}$ and $-5^{\circ} \mathrm{C}$. Spring frogs had comparatively low levels of the urea in blood plasma, liver, heart, brain, and skeletal muscle, as well as a smaller hepatic reserve of glycogen, which is converted to glucose after freezing begins. Consequently, following freezing $\left(-2.5^{\circ} \mathrm{C}, 48 \mathrm{~h}\right)$ tissue concentrations of these cryoprotective osmolytes were $44-88 \%$ lower than those measured in winter frogs. Spring frogs formed much more ice and incurred extensive cryohemolysis and lactate accrual, indicating that they had suffered marked cell damage and hypoxic stress during freezing. Multiple, interactive stresses, in addition to diminished cryoprotectant levels, contribute to the reduced capacity for freeze tolerance in posthibernal frogs.
\end{abstract}

\section{Introduction}

Among temperate ectotherms, cold hardiness in its various forms is most strongly expressed during the winter months, coincident with the greatest need for protection from severe cold. Although seasonal variation in this trait is often pronounced, its physiological basis remains incompletely understood. Recent studies, particularly those using various "-omics" approaches [1], attest that the underpinnings are complex and involve a host of adaptations at multiple levels of biological organization. Elucidation of these mechanisms will require comprehensive study of organisms for which the fundamental adaptations of freeze tolerance are reasonably well known.

The relatively robust freeze tolerance exhibited by certain woodland frogs is associated with their ability to accrue high concentrations of the cryoprotectants, glucose, and/or glycerol, which during freezing are mobilized from glycogen in the liver. These compounds limit freezing injury by colligatively lowering the equilibrium freezing/melting point $\left(F P_{\mathrm{eq}}\right)$ of body fluids and, hence, reducing ice formation, and also by preserving the integrity of membranes and macromolecules, among other things $[2,3]$. Because the hepatic glycogen store is substantially reduced following hibernation and mating, spring frogs can accrue only modest amounts of these agents, and this difference purportedly is the cause of their reduced freeze tolerance [4-8]. It was recently reported [9] that some freeze-tolerant frogs also use urea as a cryoprotectant, but whether variation in urea levels also contributes to seasonality of freeze tolerance has not been investigated.

Aside from cryoprotectant levels, freeze-tolerance capacity is influenced by physiological factors such as the osmotic activity of body fluids, hydration state of the tissues, and distribution of the water between "bulk" and "bound" fractions. Investigation of the putative roles of these factors in the seasonality of freeze tolerance in vertebrates has been hampered by the rather modest limits for freezing survival in these organisms, as even fully cold-hardened frogs survive freezing to temperatures only as low as $-4^{\circ} \mathrm{C}$ to $-6^{\circ} \mathrm{C}$. Recently, however, extreme freeze tolerance was documented in wood frogs (Rana sylvatica) endemic to Interior Alaska [10]. Winter-acclimatized frogs in this subarctic population survived freezing to temperatures at least as low as $-16^{\circ} \mathrm{C}$ 
due in part to the high levels of the cryoprotectants urea, which accumulates prior to hibernation, and glucose, which is mobilized from a massive hepatic glycogen reserve at the outset of freezing. Exceptional freeze tolerance was also attributed to an unusually large proportion of body water that was "bound" (i.e., unfreezable by virtue of its close association with macromolecules).

Our present aim was to characterize freeze-tolerance capacity and physiological aspects of the freezing adaptation in a northern population of $R$. sylvatica shortly following their emergence from hibernation. Our approach was to evaluate responses for posthibernal frogs relative to those of winteracclimatized frogs from the same region by leveraging the rich data set compiled for the latter in our previous study [10]. The uniquely direct comparison that resulted provided important new insights into the mechanisms underlying seasonal variation in this remarkable cold-hardiness adaptation.

\section{Materials and Methods}

2.1. Experimental Animals. Frogs used in this study were obtained from two distinct populations, although the latitudinal separation between collecting sites was only $\sim 110 \mathrm{~km}$ and the climatic conditions were comparable. We collected $R$. sylvatica from wetlands in the Southeast Fairbanks Census Area, Alaska $\left(63.8^{\circ} \mathrm{N}, 143.6^{\circ} \mathrm{W}\right)$, during late May 2011, within approximately two weeks of their emergence from hibernation. They were air freighted to Miami University inside a cooler that contained cold packs and insulation. These "spring" frogs were communally housed in plastic containers on a substratum of damp moss and kept at $4^{\circ} \mathrm{C}$ in total darkness for 3-10 d before use in experiments.

Responses of "winter" frogs were determined previously in the course of a separate project [10], although for convenience we here include some details of their acquisition, handling, and use in experiments. Winter frogs were collected from Fairbanks North Star Borough, near Fairbanks, AK $\left(64.8^{\circ} \mathrm{N}, 147.7^{\circ} \mathrm{W}\right)$, during early August 2011 . These frogs were topically treated with tetracycline $\mathrm{HCl}$ (to inhibit infection during rearing) before being shipped to our laboratory where they were kept individually inside plastic cups on damp paper. They were acclimatized to winter conditions by housing them in a programmable environmental chamber (I-35X, Percival) and exposing them to dynamic, diel cycles of temperature and full-spectrum lighting, which, based on weather records obtained from the National Oceanic and Atmospheric Administration's National Climatic Data Center, were seasonally appropriate to their origin. At the start of this 5-week regimen, temperature varied daily from $17.0^{\circ} \mathrm{C}$ to $8.0^{\circ} \mathrm{C}$ and the photophase was $16.5 \mathrm{~h}$; at its end, in midSeptember, temperature varied daily from $13.0^{\circ} \mathrm{C}$ to $2.5^{\circ} \mathrm{C}$ and the photophase was $13.3 \mathrm{~h}$. Frogs were fed ad libitum with crickets dusted with a vitamin supplement (ReptoCal, Tetrafauna), although most refused food after the first week in September. Following acclimatization, winter frogs were kept at $4^{\circ} \mathrm{C}$, in darkness, until mid- November, when experiments were carried out.
2.2. Experimental Freezing and Thawing. Winter and spring frogs were frozen slowly and thawed gradually following a protocol that promotes survival by facilitating cryoprotective responses and presumably mimics natural freezing and thawing episodes (i.e., slow freezing followed by gradual warming). Prior to freezing the frogs, we removed any bladder fluid through a cloacal cannula, weighed them, and placed them inside separate $50-\mathrm{mL}$ polypropylene tubes. The tubes were then plugged with plastic foam and suspended in a refrigerated bath (RTE 140, Neslab) containing chilled ethanol. A thermocouple positioned against each frog's abdomen allowed us to record body temperature $\left(T_{b}\right)$ at $30 \mathrm{~s}$ intervals on a multichannel data logger (RD3752, Omega). After each frog became supercooled $\left(T_{b} \sim-1^{\circ} \mathrm{C}\right)$, we initiated freezing of its tissues by applying aerosol coolant to the tube's exterior. Freezing proceeded over the next $48 \mathrm{~h}$ during which time the frogs gradually cooled $\left(0.05^{\circ} \mathrm{Ch}^{-1}\right)$ to the ultimate $T_{b},-2.5^{\circ} \mathrm{C}$, which was reached $\sim 30 \mathrm{~h}$ after freezing commenced. A group of frogs $(n=6)$ was removed from the bath after $48 \mathrm{~h}$ of freezing and immediately euthanized to provide tissues for analysis. Additional frogs $(n=5-6)$ were frozen for $48 \mathrm{~h}$, gently removed from their tubes, and held on damp paper at $4^{\circ} \mathrm{C}$, in darkness, for $5 \mathrm{~d}$ before being euthanized and sampled. Response variables for fully-frozen frogs and thawed frogs were compared to those for a reference group ( $n=7-8)$ of frogs that were sampled directly from their containers in the cold room.

2.3. Morphometrics and Physiological Assays. Frogs were euthanized by double pithing and dissected inside a refrigerated $\left(4^{\circ} \mathrm{C}\right)$ room after being weighed and measured to determine snout-ischium length. We immediately collected blood into heparinized microcapillary tubes from an incision in the aortic trunk or ventricle of still-frozen frogs. The tubes were centrifuged ( $2000 \mathrm{~g}, \sim 5 \mathrm{~min}$ ) to isolate the plasma, which was immediately frozen in liquid $\mathrm{N}_{2}$.

Working inside the cold room, we quickly excised the liver, heart, brain, and muscle (gracilis) from the right hindlimb. We removed and weighed any coelomic fat body. The intact liver was gently blotted on laboratory tissue, weighed, and then cut into several pieces. A portion of the liver and gracilis, as well as the entire heart and brain, were immediately frozen in liquid $\mathrm{N}_{2}$. Additional portions of the liver and gracilis were blotted to remove excess surface moisture, weighed, desiccated at $65^{\circ} \mathrm{C}$, and reweighed after being thoroughly dried so that the proportion of dry residue in the fresh samples could be used in calculating the concentration of glycogen in these tissues (see below). The result for the liver sample was also used to estimate the dry mass of the entire organ. In turn, this value was used to compute hepatosomatic index (HSI, g dry liver $\mathrm{g}^{-1}$ dry body $\times 100)$ and total glycogen reserve $\left(\mu \mathrm{mol} \mathrm{g}^{-1}\right.$ dry liver $\times \mathrm{g}$ dry liver). Computation of the former required the mass of the dry body, which we determined after desiccating the carcass at $65^{\circ} \mathrm{C}$. The change in mass of the carcass during desiccation was used to estimate the initial water content of the body.

Plasma and organ samples were stored at $-80^{\circ} \mathrm{C}$ before metabolite analyses were carried out. Deproteinized organ 
extracts were prepared by homogenizing weighed, partlythawed samples in cold $7 \%(\mathrm{w} / \mathrm{v})$ perchloric acid and then neutralizing the aqueous portion of the homogenate with $\mathrm{KOH}$. These extracts, plus an aliquot of plasma, were assayed for urea, glucose, and lactate using urease, glucose oxidase, and lactate oxidase procedures (Pointe Scientific), respectively; metabolite concentrations were expressed as $\mu \mathrm{mol} \mathrm{mL}{ }^{-1}$ plasma or $\mu \mathrm{molg}^{-1}$ fresh tissue. We could not assay urea in the plasma of spring frogs that were frozen or frozen/thawed, as too little sample was available.

Extracts of liver and muscle were assayed for glycogen using an enzymatic procedure. A $100-\mu \mathrm{L}$ portion of the whole-tissue homogenate was neutralized with $\mathrm{KOH}$ and incubated with amyloglucosidase $\left(1 \mathrm{mg} \mathrm{mL}^{-1}\right)$ at $40^{\circ} \mathrm{C}$ in a $0.2 \mathrm{M}$ sodium acetate buffer, $\mathrm{pH} 4.8$. After $2 \mathrm{~h}$, the reaction was stopped by adding cold $7 \%(\mathrm{w} / \mathrm{v})$ perchloric acid and the liberated glucose was determined as described above; glycogen concentration was expressed as glucosyl units $\left(\mu \mathrm{mol} \mathrm{g}^{-1}\right.$ dry tissue) after subtracting the quantity of glucose in the sample prior to enzymatic digestion.

Plasma osmolality of unfrozen frogs was measured by vapor-pressure osmometry (5520, Wescor) or freezing pointdepression osmometry (3320, Advanced Instruments) using appropriate $\mathrm{NaCl}$ standards. We measured free hemoglobin $(\mathrm{Hb})$ in plasma of unfrozen and frozen frogs using a modification of the Drabkin's reagent protocol (Sigma). The assay was performed in a 96-well plate containing $10 \mu \mathrm{L}$ plasma and $190 \mu \mathrm{L}$ Drabkin's solution, with human Hb (H7379, Sigma) as the standard. The reaction was incubated at room temperature for $20 \mathrm{~min}$ before the absorbance at $540 \mathrm{~nm}$ was read using a microplate reader. $\mathrm{Hb}$ concentration $\left(\mathrm{mg} \mathrm{mL}^{-1}\right)$ was determined from a standard curve and then adjusted to match the sample volume/diluent volume ratio from the original protocol.

\subsection{Freeze-Tolerance Trials. We examined freeze tolerance} in spring frogs by subjecting them to experimental freezing and thawing as described in the preceding section, except that these frogs ( $n=6$ per group) were cooled to the prescribed $T_{b},-5^{\circ} \mathrm{C},-7.5^{\circ} \mathrm{C}$, or $-10^{\circ} \mathrm{C}$, over a period of 80 , 130 , and $180 \mathrm{~h}$, respectively. Following thawing at $4^{\circ} \mathrm{C}$, each frog was monitored in order to determine its general state of neuromuscular coordination and, particularly, its ability to right itself within $2 \mathrm{~s}$ after being placed on its dorsum. Our ultimate survival criterion was exhibition of this "righting reflex" within 1 week of thawing.

2.5. Statistical Analysis. Morphometric and physiological variables were compared between winter and spring frogs using Student's $t$-tests. Within each seasonal group, responses to experimental freezing and thawing were compared using Analysis of Variance (ANOVA); means for fully-frozen and frozen/thawed groups were distinguished from that of reference (unfrozen) frogs using Dunnett's post-hoc test. Two-factor ANOVA (season $\times$ experimental treatment) was used to compare responses between seasonal groups, with Bonferroni tests used to distinguish between select pairs of means. Some data (particularly metabolite concentrations) required transformation before they met the parametric assumptions of normality and homoscedasticity. In the case of plasma $\mathrm{Hb}$ concentration, normality could not be tested for one sample that contained too few values; thus, these data were analyzed using the nonparametric Mann-Whitney test. Statistical procedures were performed using JMP 10.0.0 (SAS Institute, Inc.) or Instat 3.0 (GraphPad Software); significance was judged at $P<0.05$. All values presented in the text, tables, and figures are means \pm SEM.

\section{Results}

3.1. Morphometrics and Physiology. Spring frogs weighed $\sim 55 \%$ more and were $14 \%$ longer than winter frogs (Table 1). The larger size of these individuals probably reflected that the sample was composed almost entirely (except for one individual) of adult males, which were collected adjacent to breeding areas. In contrast, our sample of winter frogs, which was gathered in late summer when sexual dimorphism is not apparent, included males and females (32\%), as well as a few subadults, albeit no recent metamorphs.

There was congruence between winter and spring frogs in several of the response variables (Table 1). Body water content was comparable ( $80 \%$ of fresh mass), and frogs in neither group contained much fat body. Additionally, all frogs had large amounts of glycogen in muscle tissue, as concentrations exceeded $500 \mu \mathrm{mol}$ glucosyl units $\mathrm{g}^{-1}$ dry tissue. On the other hand, we found marked differences in certain hepatic variables between winter and spring frogs. Relative mass of the liver, as represented by the HSI, was 2.8fold greater in winter frogs. The larger livers of these frogs had a 2.4-fold higher concentration of glycogen and their hepatic glycogen reserve was four times as great as that of spring frogs. Glycogen richness, which relates the hepatic glycogen reserve to the amount of somatic tissue requiring cryoprotection, was 6.2-fold greater in winter frogs.

Frogs of the two groups had similar glycemic levels, but winter frogs had plasma urea levels almost $100 \mu \mathrm{mol} \mathrm{mL} \mathrm{m}^{-1}$ higher than those in spring frogs. Due in part to the abundance of this solute, winter frogs had a markedly higher (2.24-fold) plasma osmolality (Table 1).

3.2. Physiological Responses to Freezing and Thawing. Freezing commenced when the $T_{b}$ approached $-1^{\circ} \mathrm{C}$ and was denoted by an exotherm in the $T_{b}$ record for each frog. Observations made during tissue harvesting attested that spring frogs sampled $48 \mathrm{~h}$ after freezing began contained substantial amounts of ice in the coelom, beneath the skin, and within the muscles. In contrast, winter frogs contained much less ice, which was primarily confined to subcutaneous spaces, and were relatively pliable. Frogs sampled $5 \mathrm{~d}$ after thawing began appeared grossly similar to unfrozen (reference) frogs. Except one winter frog, which was omitted from analyses, all of these frogs exhibited normal neurobehavioral functions and met our survival criterion.

3.2.1. Changes in Metabolites. In winter frogs, experimental freezing was accompanied by a decrease $\left(F_{2,18}=17.3\right.$, 
TABLE 1: Somatic and physiological characteristics of wood frogs sampled in winter and spring.

\begin{tabular}{|c|c|c|c|c|}
\hline & Winter & Spring & $t$ & $P$ \\
\hline Body mass (g) & $7.2 \pm 0.5$ & $11.1 \pm 0.5$ & 5.20 & 0.0002 \\
\hline Snout-ischium length $(\mathrm{cm})$ & $4.3 \pm 0.1$ & $4.9 \pm 0.1$ & 3.87 & 0.002 \\
\hline Body water content $\left(\mathrm{gg}^{-1}\right)$ & $3.91 \pm 0.05$ & $4.03 \pm 0.10$ & 0.86 & 0.417 \\
\hline Coelomic fat body (mg) & $1.5 \pm 0.8$ & $4.5 \pm 1.6$ & 1.64 & 0.126 \\
\hline Muscle glycogen $\left(\mu \mathrm{mol} \mathrm{g}^{-1}\right)$ & $533 \pm 42$ & $508 \pm 97$ & 0.24 & 0.812 \\
\hline Hepatosomatic index & $22.4 \pm 0.9$ & $8.0 \pm 1.4$ & 9.07 & $<0.0001$ \\
\hline \multicolumn{5}{|l|}{ Liver glycogen } \\
\hline Concentration $\left(\mu \mathrm{mol} \mathrm{g}^{-1}\right)$ & $3549 \pm 88$ & $1500 \pm 404$ & 4.96 & 0.003 \\
\hline Total reserve $(\mu \mathrm{mol})$ & $1170 \pm 97$ & $294 \pm 97$ & 6.24 & $<0.0001$ \\
\hline Richness ( $\mu \mathrm{mol} \mathrm{g}^{-1}$ frog) & $794 \pm 33$ & $128 \pm 37$ & 13.20 & $<0.0001$ \\
\hline \multicolumn{5}{|l|}{ Plasma } \\
\hline Glucose $\left(\mu \mathrm{mol} \mathrm{mL} L^{-1}\right)$ & $7.2 \pm 1.3$ & $7.1 \pm 1.6$ & 0.01 & 0.991 \\
\hline Urea $\left(\mu \mathrm{mol} \mathrm{mL} L^{-1}\right)$ & $105.8 \pm 9.7$ & $8.6 \pm 1.4$ & 9.92 & $<0.0001$ \\
\hline Osmolality (mosmol kg$\left.{ }^{-1}\right)$ & $419 \pm 9$ & $187 \pm 2$ & 25.51 & $<0.0001$ \\
\hline$n$ & 8 & 7 & & \\
\hline
\end{tabular}

Note: Values are mean \pm SEM. Comparison between winter and spring groups was made using unpaired Student's $t$-test. Data from winter frogs were initially reported in Costanzo et al. [10].

$P=0.0001)$ in liver glycogen concentration, which fell $\sim 39 \%$ from the concentration in unfrozen frogs, $3549 \pm 88 \mu \mathrm{mol} \mathrm{g}^{-1}$ dry tissue (Figure 1). The level rebounded during thawing, as the concentration in thawed frogs was indistinguishable from that in unfrozen frogs. Spring frogs also showed a decrease in liver glycogen concentration during freezing, followed by replenishment upon thawing $\left(F_{2,16}=24.8, P<0.0001\right)$, but this dynamic differed in some respects from that seen in winter frogs $\left(F_{5,32}=16.9, P<0.0001\right)$. Notably, the hepatic glycogen level in unfrozen frogs, $1500 \pm 404 \mu \mathrm{molg}^{-1}$ dry tissue, was only $42 \%$ of that found in winter frogs $(t=3.6$, $P<0.01$ ) and dropped much more severely (by $95 \%$ ) during freezing.

Winter frogs exhibited changes $\left(F_{2,16}=140.1, P<\right.$ 0.0001 ) in glycemia that mirrored the freezing and thawing dynamic with liver glycogen (Figure 2). This was also the case with spring frogs $\left(F_{2,13}=66.9, P<0.0001\right)$, although the pattern of change differed between the groups $\left(F_{5,29}=59.0\right.$, $P<0.0001)$. Although plasma glucose levels in all unfrozen frogs were uniformly low $\left(\sim 7 \mu \mathrm{mol} \mathrm{mL}^{-1} ; P>0.05\right)$, levels in winter frogs exceeded those in spring frogs in both frozen $(P<0.01)$ and thawed individuals $(P<0.01)$. Glycemic levels fell appreciably after thawing in spring frogs, but not in winter frogs, which remained strongly hyperglycemic ( $85.0 \pm$ $13.4 \mu \mathrm{mol} \mathrm{mL} L^{-1}$ ).

Winter frogs exhibited a strong increase with freezing and subsequent reduction after thawing in glucose levels in liver $\left(F_{2,16}=433.2, P<0.0001\right)$, heart $\left(F_{2,18}=430.7\right.$, $P<0.0001)$, brain $\left(F_{2,18}=251.5, P<0.0001\right)$, and muscle $\left(F_{2,16}=677.3, P<0.0001\right.$; Figure 2$)$. Concentrations in frozen frogs were 54- to 80 -fold higher than those in unfrozen frogs, the actual levels varying by organ, being highest in liver $\left(194 \pm 16 \mu \mathrm{mol} \mathrm{g}^{-1}\right.$ fresh tissue) and lowest in muscle ( $62 \pm 3 \mu \mathrm{molg}^{-1}$ fresh tissue). Organs of spring frogs exhibited grossly similar patterns of change (liver:

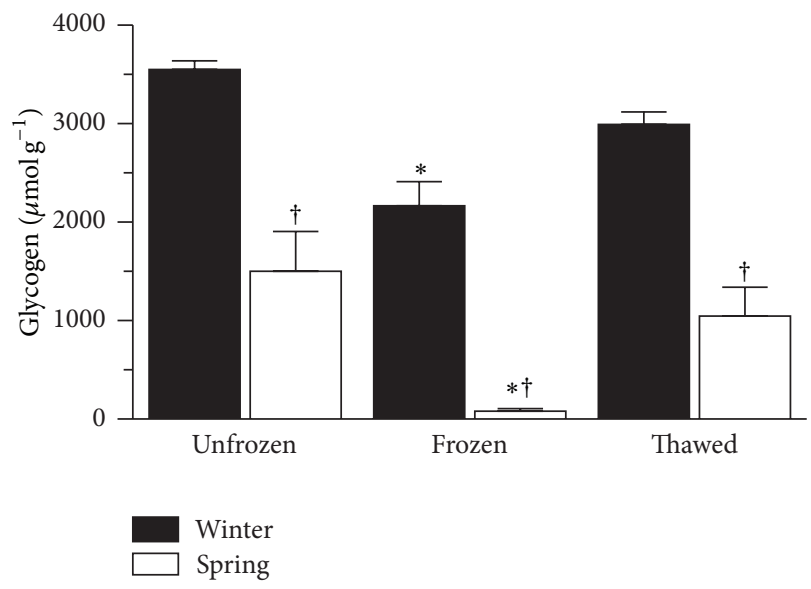

FIGURE 1: Variation in liver glycogen concentration ( $\mu$ mol glucosyl units $\mathrm{g}^{-1}$ dry tissue) associated with experimental freezing $(n=6)$ and thawing $(n=5-6)$ of winter and spring wood frogs. A mean identified by an asterisk differed $(P<0.05)$ from the corresponding mean for unfrozen frogs $(n=7-8)$. A dagger indicates that the mean for spring frogs differed $(P<0.05)$ from the corresponding mean for winter frogs. Data from winter frogs were initially reported in Costanzo et al. [10].

$F_{2,16}=59.5, P<0.0001$; heart: $F_{2,16}=133.4, P<0.0001$; brain: $F_{2,16}=99.1, P<0.0001$; muscle: $F_{2,16}=10.6$, $P=0.001)$. However, their responses to freezing and thawing differed from those of winter frogs (liver: $F_{5,32}=28.5, P<$ 0.0001; heart: $F_{5,32}=104.2, P<0.0001$; brain: $F_{5,32}=$ 114.1, $P<0.0001$; muscle: $F_{5,32}=16.1, P<0.0001$ ) because they accrued much less glucose with freezing and/or more substantially reduced the glucose level after thawing. The case with liver was exceptional: during freezing, spring frogs accumulated as much glucose in this organ as did 


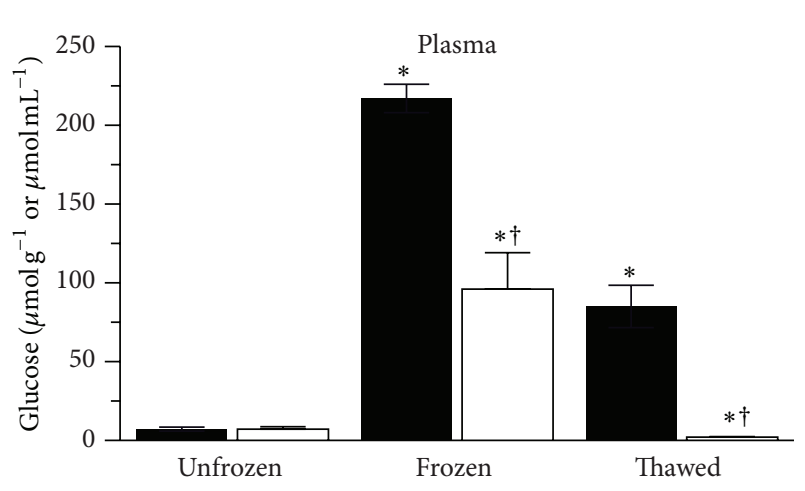

(a)

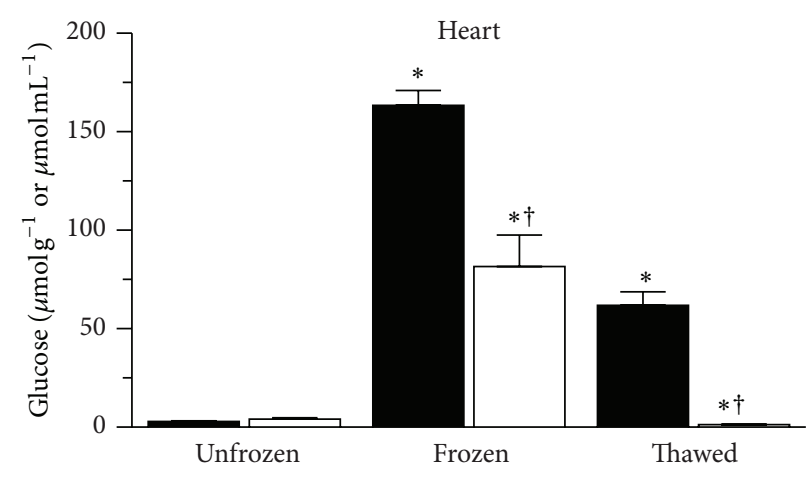

(c)

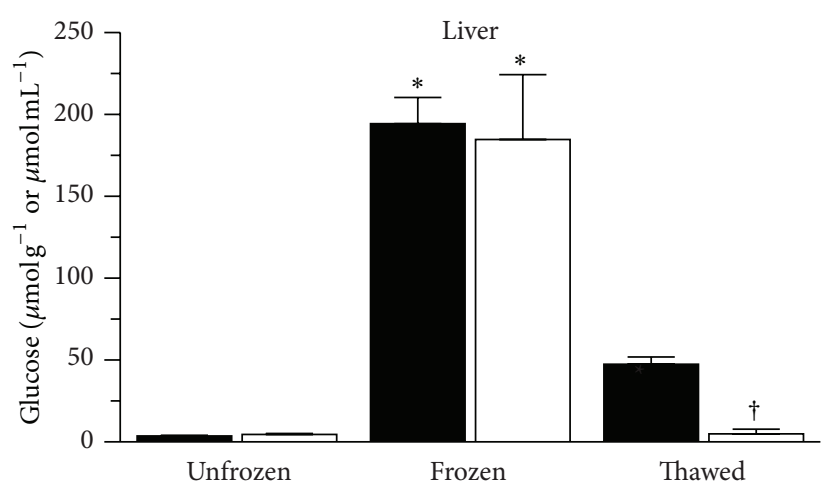

(b)

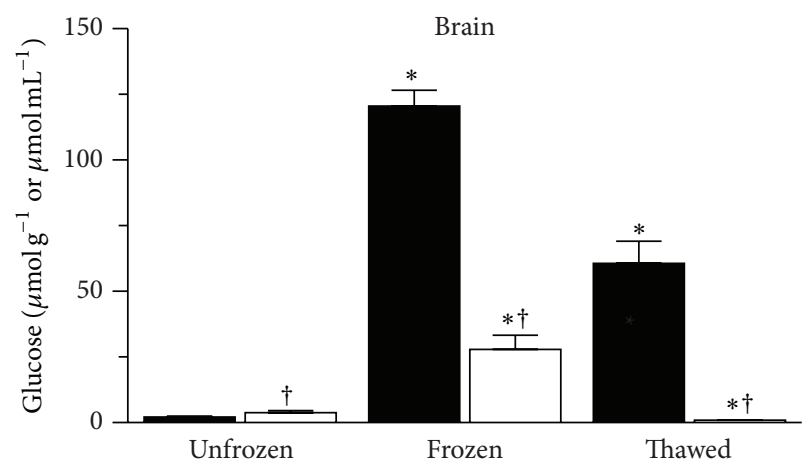

(d)

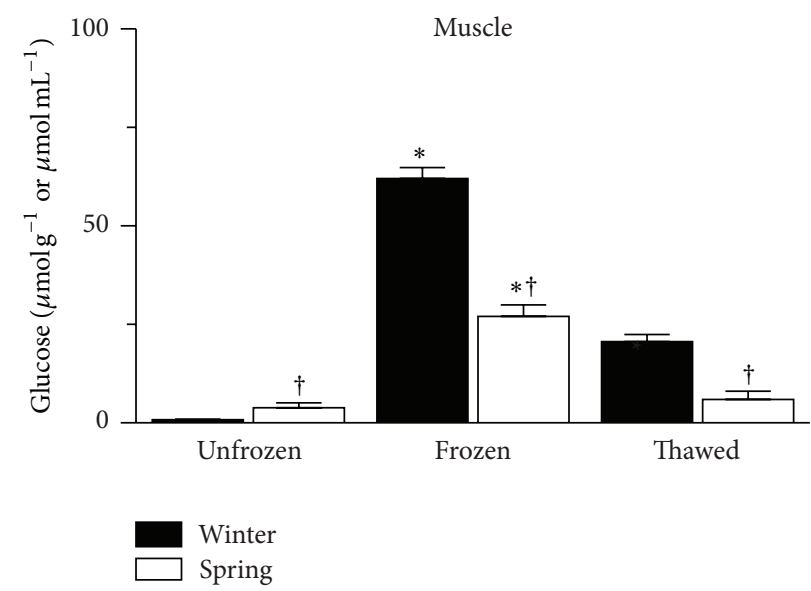

(e)

FIGURE 2: Variation in glucose concentration in blood plasma and several organs ( $\mu \mathrm{mol} \mathrm{g}^{-1}$ fresh tissue) associated with experimental freezing and thawing of winter and spring wood frogs. Sample sizes and symbology as in Figure 1. Data from winter frogs were initially reported in Costanzo et al. [10].

winter frogs (spring: $185 \pm 40 \mu \mathrm{mol} \mathrm{g}^{-1}$ fresh tissue; winter: $194 \pm 16 \mu \mathrm{mol} \mathrm{g}^{-1}$ fresh tissue; $P>0.05$ ) but upon thawing reduced the glucose level to that of their unfrozen counterparts.

Urea accrued in liver during freezing of winter frogs, the concentration reaching $157 \pm 10 \mu \mathrm{molg}^{-1}$ fresh tissue, substantially higher $\left(F_{2,16}=9.5, P=0.002\right)$ than that found in unfrozen frogs, $114 \pm 6 \mu \mathrm{mol} \mathrm{g}^{-1}$ fresh tissue, but returned to the reference level after thawing (Figure 3). Hepatic urea levels in spring frogs also varied $\left(F_{2,13}=5.7, P=0.013\right)$ with freezing and thawing, but, despite exhibiting a similar pattern of response $\left(F_{5,32}=1.4, P=0.27\right)$, were only 6 $8 \%$ of those found in winter frogs. Similarly, urea levels in heart, brain, and muscle were much lower in spring frogs as compared to winter frogs $(P<0.001$, all cases $)$. Among these organs, urea concentrations were nominally higher in frozen frogs than in corresponding unfrozen frogs, but the difference was significant $\left(F_{2,16}=4.6, P=0.027\right)$ only in heart of spring frogs. In both seasonal groups, thawed frogs had urea levels comparable to those of their unfrozen counterparts. 


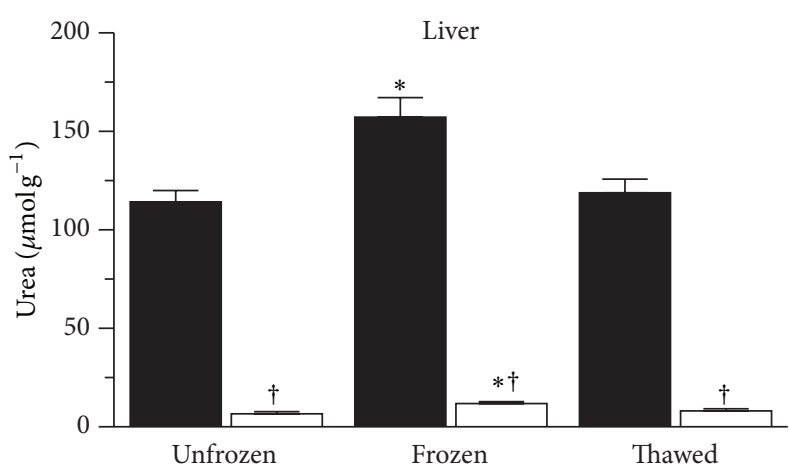

(a)

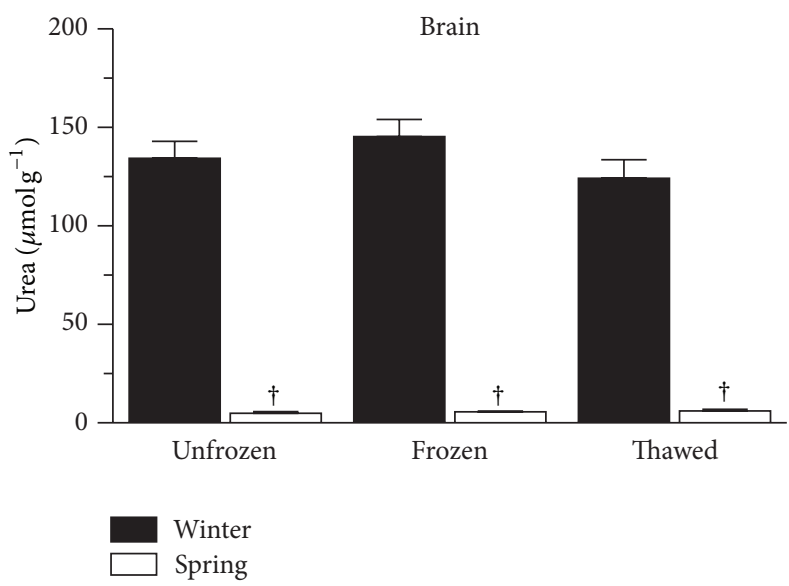

(c)

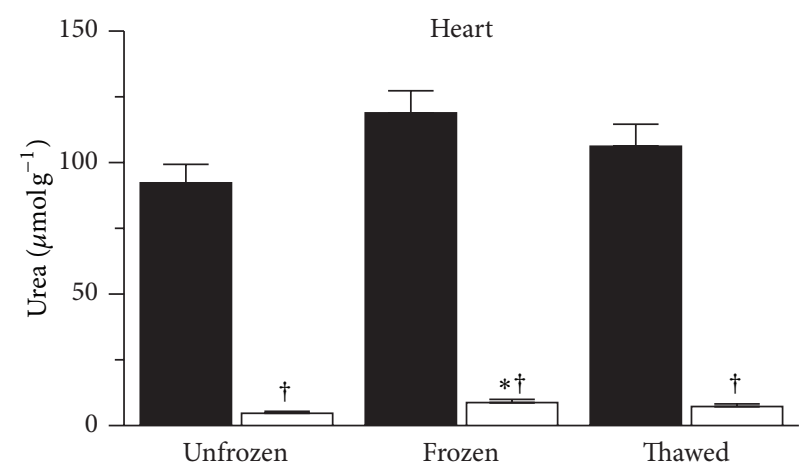

(b)

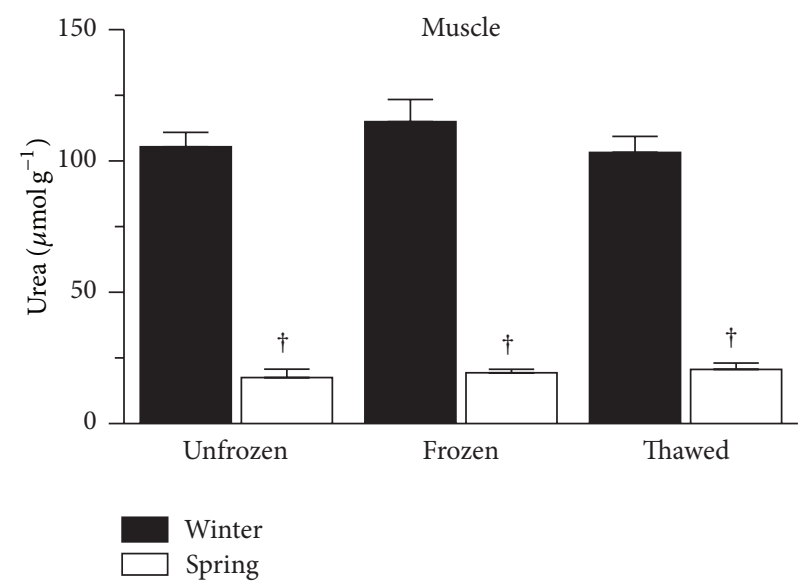

(d)

FIGURE 3: Variation in urea concentration in several organs $\left(\mu \mathrm{molg}^{-1}\right.$ fresh tissue) associated with experimental freezing and thawing of winter and spring wood frogs. Sample sizes and symbology as in Figure 1. Data from winter frogs were initially reported in Costanzo et al. $[10]$.

3.2.2. Freezing and Thawing Stress. Experimental freezing was associated with a rise in lactate concentration in the blood and organs and a subsequent reduction in lactate following thawing (Figure 4). Frozen frogs had lactemia levels higher than those of unfrozen frogs in both winter $\left(F_{2,16}=43.9, P<0.0001\right)$ and spring $\left(F_{2,16}=109.5\right.$, $P<0.0001)$ groups; however, the elevation in spring frogs, $\sim 20$-fold, was much more robust. Lactate levels in the liver, heart, brain, and muscle of unfrozen frogs generally were low (i.e., $<5 \mu \mathrm{mol} \mathrm{g}^{-1}$ ), but in some tissues differed slightly, albeit significantly $(P<0.05)$, between winter and spring groups. Organs of frozen frogs from both groups had comparatively high lactate concentrations (winter: $P<0.027$, all cases; spring: $P<0.003$, all cases), although the levels achieved in spring frogs were consistently higher than those in winter frogs $(P<0.05$, all cases). This differential was especially pronounced in heart, which accumulated lactate to $35.0 \pm$ $7.4 \mu \mathrm{mol} \mathrm{g}^{-1}$ in spring frogs but only to $5.0 \pm 0.2 \mu \mathrm{mol} \mathrm{g}^{-1}$ in winter frogs. Lactate levels in organs of thawed frogs were comparable to those in unfrozen frogs, except that lactate remained slightly elevated $(P<0.01)$ in the liver of winter frogs.

The concentration of free $\mathrm{Hb}$ in plasma, a proxy for the extent of erythrocyte damage, served to index the magnitude of freezing stress. For the winter group, plasma $\mathrm{Hb}$ concentration in frozen frogs, $2.1 \pm 0.9 \mathrm{mg} \mathrm{mL}^{-1}(n=6)$, was nominally higher than that in reference frogs, $0.8 \pm 0.2 \mathrm{mg} \mathrm{mL}^{-1}(n=$ $8)$, although the difference was not significant $(U=13.0$; $P=0.181)$. In contrast, cryohemolysis in spring frogs was considerable, as the $\mathrm{Hb}$ concentration increased robustly $(U=0.01, P=0.006)$, from $1.0 \pm 0.2(n=7)$ to $11.8 \pm$ $5.4 \mathrm{mg} \mathrm{mL}^{-1}(n=4)$.

3.3. Freezing Survival. Spring frogs subjected to freezing at $-7.5^{\circ} \mathrm{C}$ or $-10^{\circ} \mathrm{C}$ showed limited or no signs of viability following thawing and were scored as mortalities. Frogs frozen at $-5^{\circ} \mathrm{C}$ recovered slowly and, by the seventh day after thawing began, all but one, which had died, responded to tactile stimulation and showed limited neuromuscular function. We nevertheless scored all these frogs as mortalities because none exhibited the righting reflex. Indeed, during the ensuing two weeks, another died and the others showed no improvement and were euthanized. Spring frogs used in the freezing experiment (i.e., frozen at $-2.5^{\circ} \mathrm{C}$ ) met our survival criterion before being sampled $5 \mathrm{~d}$ after thawing began. Thus, we deduced that the thermal limit for freezing survival in these frogs was between $-2.5^{\circ} \mathrm{C}$ and $-5^{\circ} \mathrm{C}$. 


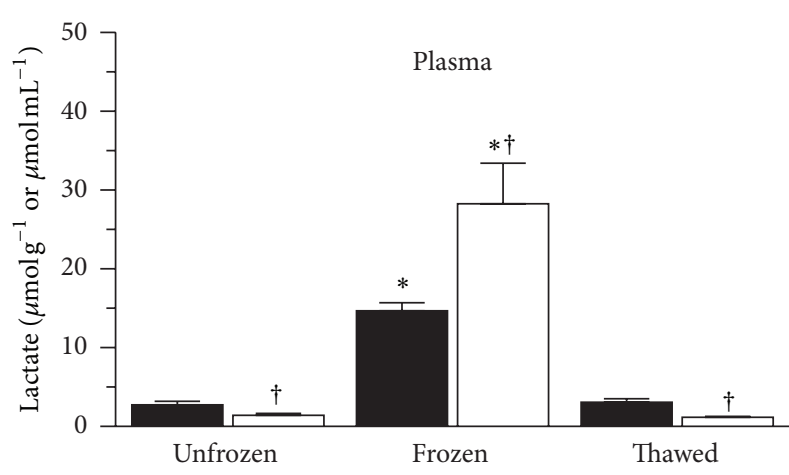

(a)

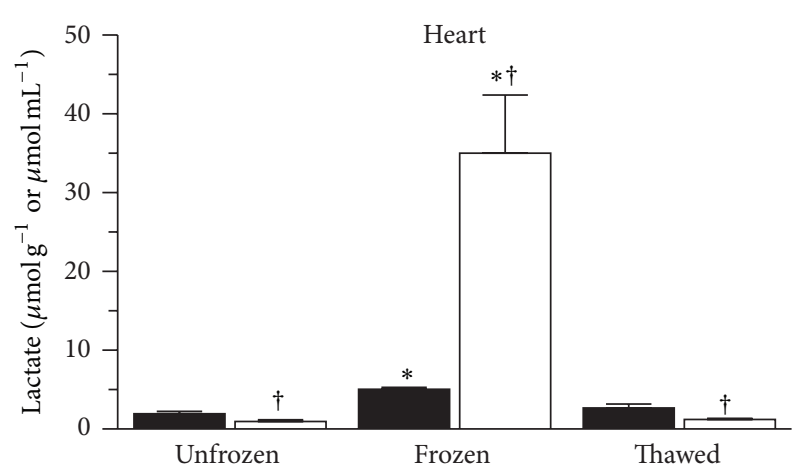

(c)

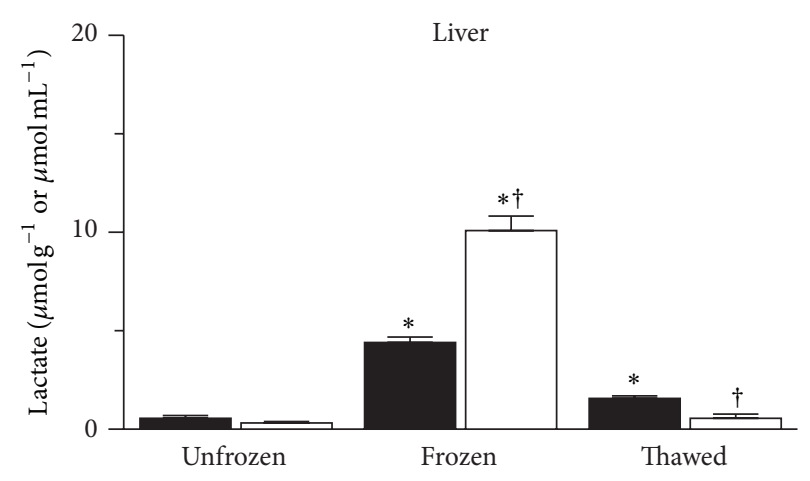

(b)

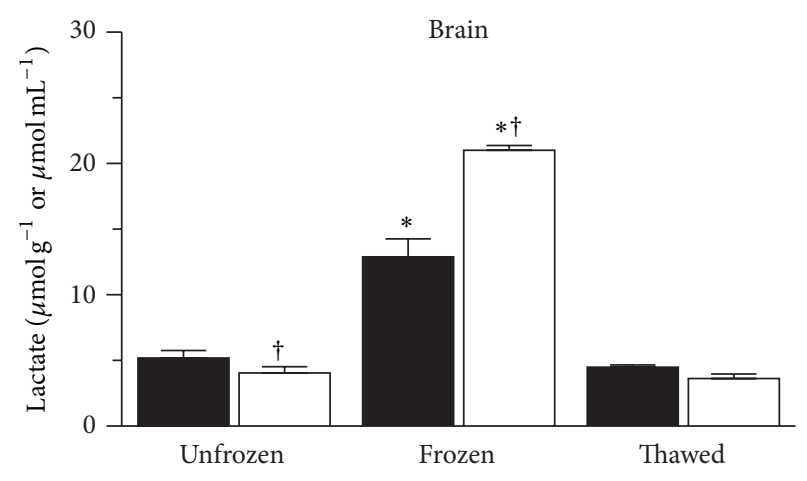

(d)

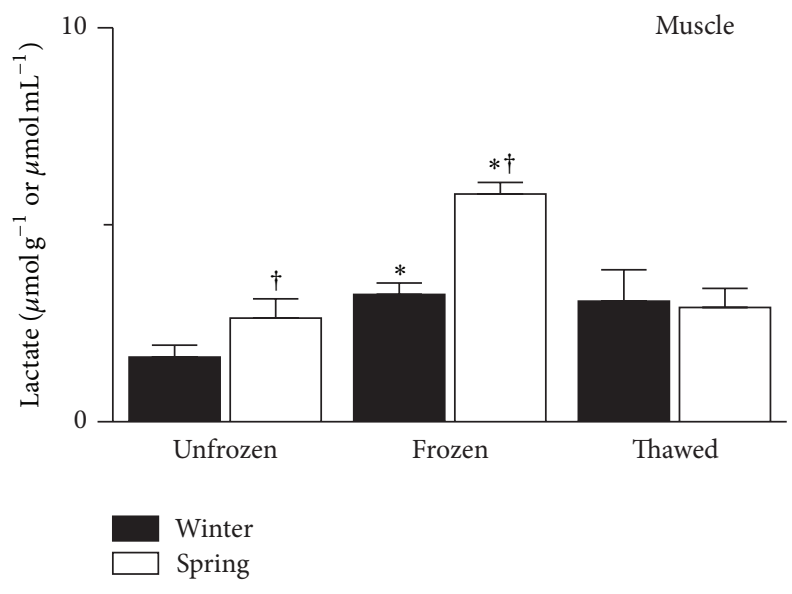

(e)

FIGURE 4: Variation in lactate concentration in blood plasma and several organs ( $\mu \mathrm{mol} \mathrm{g}^{-1}$ fresh tissue) associated with experimental freezing and thawing of winter and spring wood frogs. Sample sizes and symbology as in Figure 1. Data from winter frogs were initially reported in Costanzo et al. [10].

\section{Discussion}

4.1. Seasonal Variation in Physiology. Our purpose in this study was to investigate seasonality of freeze tolerance in a population of especially cold-adapted wood frogs with the aim of elucidating the causes underlying the variation. To that end, we compared the physiological characteristics and freeze-thaw responses of recently emerged (spring) frogs with those of fully cold-hardened, winter frogs, which were previously reported in the context of geographical variation in the freezing adaptation [10]. The resultant contrast underscored some of the fundamental mechanisms contributing to freeze tolerance, a complex, multifaceted adaptation that remains incompletely understood.

Seasonal development of freeze tolerance in ectotherms is commonly associated with accrual of one or more cryoprotective osmolytes [3]. This is true of $R$. sylvatica, which accumulates urea in autumn and early winter, coincident with seasonal reductions in environmental temperature and water potential [9]. One important role of the accrued urea is to raise the osmotic pressure of body fluids. Plasma osmolality was markedly higher in winter frogs 
(419 $\left.\mathrm{mOsmol} \mathrm{kg}{ }^{-1}\right)$ than in spring frogs $\left(187 \mathrm{mOsmol} \mathrm{kg}^{-1}\right)$, although the disparity, $232 \mathrm{mOsmol} \mathrm{kg}^{-1}$, was substantially larger than can be accounted for solely by the difference in uremia, $97 \mu \mathrm{mol} \mathrm{mL} L^{-1}$. Thus, the blood of winter frogs also contained $\sim 135 \mu \mathrm{mol} \mathrm{mL}^{-1}$ of an additional solute that includes an as yet unidentified compound(s) that is absent from conspecifics from more temperate locales [10]. This marked seasonal variation in plasma osmolality, which is seen in other freeze-tolerant frogs [11], can regulate cold hardiness by colligatively altering the $F P_{\mathrm{eq}}$ of body fluids and, thus, the amount of ice that forms at any given $T_{b}$.

High urea also promotes overwintering survival in $R$. sylvatica by contributing to an energy-conserving metabolic depression [12]. This effect may particularly benefit Alaskan frogs, which subsist on stored nutrient reserves in hibernation for nearly eight months each year [13]. In spring, frogs presumably must clear accrued urea in order to terminate dormancy and resume behavioral activities, such as mating. Accordingly, urea levels in our spring frogs were substantially lower than those of winter frogs.

In Alaskan R. sylvatica, autumnal sequestration of urea is promoted by an influx of nitrogen derived from muscle catabolism, a process that also contributes to glycogenesis in liver and muscle [10]. Given that mating immediately follows hibernal emergence and that reproductive success demands arduous physical activity $[14,15]$, the cost-benefit implications of subsidizing cryoprotectant production with muscle protein are interesting to contemplate. Muscle atrophy resulting in impairment of locomotor and swimming performance potentially could diminish reproductive fitness, but this possibility has not yet been investigated [16].

Temperate amphibians exhibit distinct, seasonal patterns of nutrient cycling that sustain vital functions during periods of aphagia, such as hibernation. A comprehensive winter energy budget for $R$. sylvatica is lacking, although one study [17] estimated costs from respirometry data and microclimate temperatures. A key assumption in this model was that lipids constitute a primary energy substrate whilst frogs are hibernating in an unfrozen state. However, triglyceride reserves actually may be scarce during winter, as they are commonly diminished or depleted during the prehibernal period in order to sustain metabolism and, by way of the glycerol moiety serving as a precursor to gluconeogenesis, build other nutrient depots [18-20]. Similarly, in R. sylvatica, coelomic fat body, which presumably is highly correlated to total body lipid [21], is severely reduced or eliminated prior to hibernation [10] and, consequently, our spring (and winter) frogs had insignificant lipid reserves, as has been reported previously [22].

Winter frogs had a substantial amount of glycogen stored in skeletal muscle, but this reserve apparently contributes little to meeting the energy demands in hibernation, as there was no difference in muscle glycogen between winter and spring frogs. Our results concur with previous findings that the glycogen level in muscle of freeze-tolerant frogs is invariable from autumn to spring $[4,23]$. Conserving this substrate during winter would ensure its availability in spring to fuel the muscular work necessitated by reproductive activities $[8,22]$.

Among temperate anurans, the liver glycogen depot commonly is largest in autumn or early winter and smallest in spring [24]. This pattern is also seen in R. sylvatica, as the reserve in our spring frogs was only $~ 25 \%$ of that found in winter frogs. Apparently, much of this depletion occurs during spawning rather than during winter, per se, because the amount present at the end of hibernation is little changed from autumn levels [4, 25, 26]. Glycogen sparing in hibernation not only enhances the cryoprotectant mobilization response to freezing but also ensures that frogs retain the ample energy stores needed for reproductive success. Indeed, capital breeding can consume much of the energy reserves remaining after hibernation [20] and, as $R$. sylvatica reportedly does not feed whilst mating [22], its hepatic glycogen content is markedly reduced (by $50-75 \%$ in some studies) within a few weeks following emergence $[4,26]$.

4.2. Seasonality of Freeze Tolerance. As with most forms of cold hardiness, freeze tolerance is more robust during winter than at other times of the year. This tenet reportedly applies to woodland frogs $[4-8,27,28]$, although the observed variation is not particularly great, given that most freeze-tolerant vertebrates can survive freezing to temperatures only as low as $-4^{\circ} \mathrm{C}$ to $-6^{\circ} \mathrm{C}$ [2]. For example, in a study of $R$. sylvatica from western Pennsylvania, USA, frogs recovered from freezing at $-5^{\circ} \mathrm{C}$ in autumn, but in early June survived only a brief period of freezing at $-1.5^{\circ} \mathrm{C}$ [7]; thus, the change was only a few degrees. Our present findings showed a much more dramatic effect of season. Indeed, frogs adapted to the subarctic climate of Interior Alaska can survive freezing to temperatures at least as low as $-16^{\circ} \mathrm{C}$ when winter acclimatized [10], but following emergence from hibernation will die at temperatures between $-2.5^{\circ} \mathrm{C}$ and $-5^{\circ} \mathrm{C}$.

Freeze-tolerant animals can survive the freezing of up to approximately two-thirds of their body water [3]. Although this critical limit does not vary with season, much less ice is formed in autumn/winter frogs than in spring/summer frogs at any given $T_{b}[5,7,27]$. Our dissections of frozen frogs showed that this was also true in the present study. Such variation undoubtedly reflects marked differences in osmotic potential, which is strongly influenced by the levels of lowmolecular-mass cryoprotectants accumulated before and/or during freezing. Indeed, considerable empirical evidence links body ice content to cryoprotectant level in freezetolerant frogs $[7,29,30]$.

Ice content is also influenced by the relative amounts of bulk water and bound water within tissues. An increase in the fraction of water that is bound (i.e., associated with solutes, macromolecules, surfaces, and other cellular structures in a manner that renders it unfreezable) is an important aspect of seasonal cold hardening in some ectotherms [7, 27, 31]. One effect of increasing the bound water fraction is to depress the $T_{b}$ at which the lethal ice content is attained. Notably, the exceptional freeze tolerance in winter Alaskan frogs as compared to conspecifics from a more temperate locale 
(Ohio, USA) is explained in part by their larger bound water fraction (>26\% versus 15\%, respectively; [10]). Given that the difference in tissue $F P_{\text {eq }}$ between our winter and spring frogs is only $\sim 0.6^{\circ} \mathrm{C}$, the loss of freeze tolerance following hibernal emergence must involve a substantial reduction in bound water.

Winter-acclimatized frogs from the population under investigation can tolerate a continuous bout of freezing (at $-4^{\circ} \mathrm{C}$ ) lasting two months [10], much longer than can be survived by frogs indigenous to more temperate locales [7, 32]. Little is known about seasonality of freeze endurance, although a study of Hyla versicolor showed that winter frogs survived longer bouts of freezing than did frogs collected in June [27]. Accordingly, we conjecture that freeze endurance in Alaskan R. sylvatica is also reduced in spring as compared to winter.

\subsection{Seasonal Variation in Responses to Freezing and Thawing.} Freezing-induced mobilization of the cryoprotectant glucose is a storied adaptation in anuran freeze tolerance, the process beginning within minutes of ice nucleation and continuing for many hours, diminishing only after freezing reaches an advanced stage or the glycogen reserve is exhausted [3]. In the present study, frogs tested in both seasons exhibited a strong glycogenolytic response to freezing, although the quantity of substrate (expressed as glucosyl units) converted to glucose was much greater in winter frogs $(741 \mu \mathrm{mol})$ than in spring frogs $(286 \mu \mathrm{mol})$. In addition, within $48 \mathrm{~h}$ of freezing, spring frogs had virtually depleted their glycogen reserve, whereas winter frogs had about two-thirds of theirs remaining. This stark disparity in cryoprotectant synthesis capacity largely reflects the very different amounts of substrate in these frogs. Indeed, the liver of winter frogs contained nearly $1,200 \mu \mathrm{mol}$ of glycogen, which contributed to the remarkable size of this organ, some $22 \%$ of total body mass. In contrast, the liver of spring frogs was much smaller (HSI, 8\%) and contained only one-fourth as much glycogen. This distinction is particularly instructive if the glycogen reserve is considered relative to the quantity of tissue requiring cryoprotection: the supply in winter frogs was more than six times as great (Table 1).

The modest hepatic glycogen depot in spring frogs generally accounted for the relatively low levels of glucose found in their frozen tissues. However, the large disparity in glucose levels between the liver and blood suggests that hepatic export was a bottleneck to the delivery of cryoprotectants to extrinsic tissues. Diminished efflux in spring frogs could reflect seasonally reduced numbers of glucose transporters at the hepatocyte membrane, which has been reported [33]. Additionally, glucose levels in nonhepatic tissues, which were only $23-50 \%$ of those achieved in winter frogs, varied markedly, probably due to differences in the blood supply and/or efficiency of glucose uptake. In frozen frogs, glucose levels typically are highest in liver (the solute's source), intermediate in organs that are perfused for longer periods, such as brain and heart, and lowest in organs that freeze quickly and are sooner isolated from the blood supply, such as limb muscles [3]. This pattern was evident in our winter frogs, but spring frogs showed an important deviation in that glucose levels in brain were uncharacteristically low. This result, coupled with high levels of lactate, suggest that blood flow to this sensitive organ was prematurely interrupted.

In frogs from temperate populations, much of the excess glucose mobilized during freezing is quickly cleared from most tissues, potentially within a few days of thawing [34]. However, in our winter Alaskan frogs, much glucose remained in the tissues (especially brain) even $5 \mathrm{~d}$ after thawing began. Delayed clearance of this compound has been associated with high levels of urea [10], which potentially exact an inhibitory effect on glycogen synthase, the enzyme regulating the rate of glucose clearance in thawed frogs [35]. Maintaining the hyperglycemic state well beyond thawing could benefit winter frogs by ensuring that cells have an abundance of the metabolic fuel needed to repair damage, which can be an energetically demanding process $[17,36$, 37] and by supplementing cryoprotectant levels during subsequent freezing exposures. Spring frogs apparently lacked this benefit, as their glucose levels had either returned to (liver, muscle) or dropped below (heart, brain, plasma) prefreeze levels within the recovery period. In these frogs, hypoglycemia probably resulted because glucose filtered by the kidneys was sequestered in the urine. Layne et al. [6], who examined urine composition of $R$. sylvatica shortly after thawing, found that glucose levels in the urine and blood were similar in winter frogs, but in spring frogs the concentration in urine was nearly twice that in plasma. Conceivably, this condition could reflect a diminished capacity for glucose reabsorption by urinary bladder (see Costanzo et al. [38]). Ultimately, however, the restricted supply of glucose to tissues could have hampered postfreeze recovery in these frogs.

Winter frogs had high levels of urea in blood plasma $\left(106 \mu \mathrm{mol} \mathrm{mL} L^{-1}\right)$ and other tissues $\left(92-134 \mu \mathrm{mol} \mathrm{g}^{-1}\right)$, this compound having accrued during the prehibernal period [10]. By contrast, urea concentrations in tissues of spring frogs were much lower $\left(5-18 \mu \mathrm{mol} \mathrm{g}^{-1}\right)$, albeit representative of the levels found in active frogs with unrestricted urine flow and water turnover [39]. Although corporal freezing stimulated urea synthesis in the liver of both winter and spring frogs, the increment in urea was modest, being only $\sim 5 \mu \mathrm{mol} \mathrm{g}^{-1}$ in spring frogs. The comparable increase seen in heart could have resulted from ureagenesis within cardiomyocytes [40]; however, most nonhepatic tissues failed to accumulate urea during freezing.

Aside from their colligative effects on $F P_{\text {eq }}$ and, therefore, ice content, cryoprotectants help maintain the structural and functional integrity of cells and tissues in the face of freezing and thawing stresses. Glucose is an important substrate fueling anaerobic metabolism in frozen tissues and also stabilizes cell membranes [41]. In moderate concentrations, urea is a membrane stabilizer [42, 43], has antioxidative properties [44], and protects macromolecules from hypersalinity damage [45]. It follows that the markedly diminished capacity for freeze tolerance in our spring frogs at least partly reflects their meager ability to accrue these agents. Other studies have also shown that the amount of carbohydrate cryoprotectant (glucose or glycerol) synthesized by freezetolerant frogs in spring or early summer is markedly reduced 


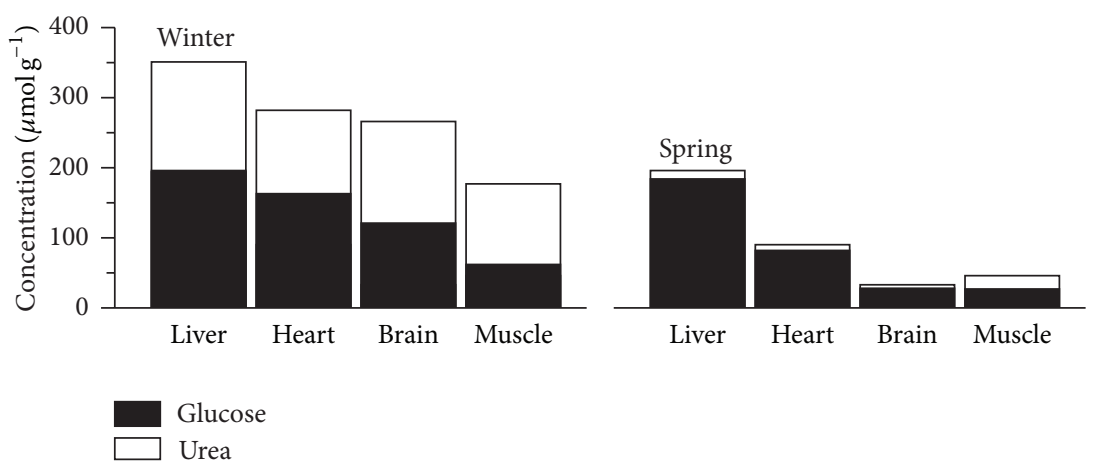

FIGURE 5: Relative contribution of urea and glucose to total cryoprotectant load in several organs of winter and spring wood frogs sampled after experimental freezing. Derived from values for group means as depicted in Figures 2 and 3. Data from winter frogs were initially reported in Costanzo et al. [10].

from that accumulated in fall or winter [4-8]. Our present results demonstrate an even more striking disparity with urea, which contributes substantially to the total cryoprotectant load in winter frogs (Figure 5). Notably, in brain tissue the concentration of urea and glucose combined was $266 \mu \mathrm{mol} \mathrm{g}^{-1}$ in winter frogs but only $33 \mu \mathrm{molg}^{-1}$ in spring frogs. Insufficient cryoprotectant levels in this organ could be highly detrimental, as nervous tissue is especially sensitive to cryoinjury $[46,47]$.

4.4. Seasonal Variation in Freezing and Thawing Stress. Freezing of biological tissues provokes metabolic and homeostatic perturbations, hypoxic and oxidative damage, and osmoionic injury to macromolecules, organelles, and membranes [2, 3 , 48]. Critically damaged cells typically leak cytoplasmic elements, which can be detected at unusual levels in the blood. Accordingly, we used the plasma concentration of $\mathrm{Hb}$ to gauge the degree of intravascular hemolysis caused by freezing. The relatively low level of this marker in our winter frogs suggests that such damage was minimal, a likely consequence of their high levels of glucose and urea. By contrast, spring frogs, which had much lower concentrations of these cryoprotectants, incurred extensive damage to erythrocytes (and, presumably, other types of cells) likely owing to greater shrinkage and membrane injury.

Interruption of the blood flow to tissues during freezing can cause disruption of oxidative phosphorylation, depletion of creatine phosphate and ATP stores, reactive-oxygen species (ROS) accumulation, and metabolic acidosis. In contrast to the case with our winter frogs, spring frogs had large amounts of lactate in their blood and organs, indicating that they suffered severe hypoxic stress during freezing. Indeed, these levels approximated concentrations achieved in $R$. pipiens exposed to anoxia for 4-6 d [49]. Churchill and Storey [5] found that lactemia in frozen $R$. sylvatica was greater in spring versus autumn, although the difference was not quite statistically significant, perhaps because the freezing episode experienced by their frogs was relatively mild $\left(-2^{\circ} \mathrm{C}\right.$ for $\left.24 \mathrm{~h}\right)$. Undue hypoxic stress in our spring frogs, which suggests that they formed ice too quickly, used oxygen reserves inefficiently, and/or failed to adequately reduce metabolic demands during freezing, may have contributed to their poor freeze tolerance. Indeed, the decreased intracellular $\mathrm{pH}$ arising from lactacidosis is a serious cellular distress associated with freezing mortality in $R$. sylvatica [41]. Given that oxidative stress accompanies arousal from hibernation [50], perhaps these frogs had preexisting damage to macromolecules and membrane lipids that predisposed them to hypoxic stress induced during experimental freezing and thawing.

The especially high level of lactate in the heart of spring frogs suggests that this organ incurred an exceptional level of hypoxic stress (Figure 4). Unlike the case with amphibian skeletal muscle, which can readily neutralize lactic acid, cardiac tissue is highly susceptible to damage from lactate accumulation [51], and this may have contributed to the reduced freeze tolerance in spring frogs. On the other hand, metabolic acidosis is partly countered by buffering from bicarbonate and calcium carbonate [52], and the seasonally high levels of bicarbonate in the plasma of some winter frogs (e.g., [53]) may help limit such damage. Furthermore, winter frogs also benefit from high levels of urea, which apparently protect against reperfusion injury to the myocardium [44].

\section{Conclusion}

Wood frogs indigenous to Interior Alaska, near the northern limit of their geographical range, exhibit a remarkably profound level of freeze tolerance that is consistent with the demands imposed by the harsh, subarctic climate. However, this capacity was strongly seasonally labile, being reduced by over $10^{\circ} \mathrm{C}$ within a brief period following hibernal emergence. Our results indicate that this disparity at least partly derives from differential abilities to accumulate two osmolytes, urea and glucose, that function to minimize damage from freezing and thawing stress. It apparently involves other factors, such as differences in the bound water fraction and ability to manage hypoxic stress.

Throughout their range, $R$. sylvatica is the earliest breeding of all anurans, with individuals commonly migrating to vernal pools even whilst snow still covers the ground and frost threatens $[4,14,15,34]$, sometimes with lethal 


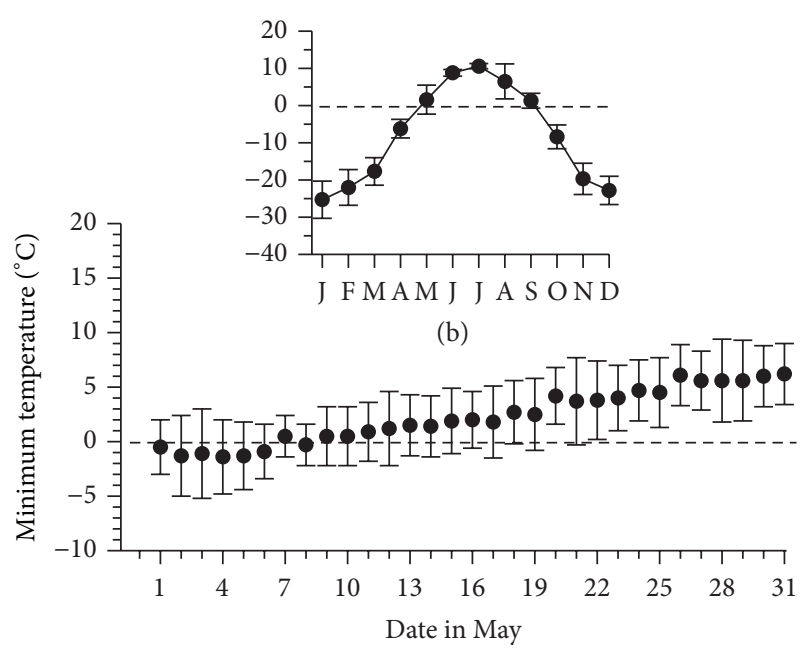

(a)

FIgURE 6: Minimum air temperature for each day in May (a) and monthly mean minimum air temperatures (b) recorded at University Experiment Station, near Fairbanks, AK $\left(64.85^{\circ} \mathrm{N}, 147.86^{\circ} \mathrm{W}\right.$; $145 \mathrm{~m}$ elevation). Data are mean \pm SD computed for temperatures recorded during the 30-year period, 1983-2012. Dashed line represents the $F P_{\text {eq }}$ of body fluids.

consequences [54]. Retaining a measure of freeze tolerance seems adaptive because, in the temperate portions of its range, the potential for freezing persists throughout the breeding period. By contrast, in Interior Alaska, breeding typically occurs throughout May [55], a month characterized by rapidly rising temperatures (Figure 6). Accordingly, the indigenous frogs exhibit a substantially reduced capacity for freeze tolerance that seems well matched to their limited risk of freezing exposure during this time.

\section{Conflict of Interests}

The authors declare that there is no conflict of interests regarding the publication of this paper.

\section{Acknowledgments}

The authors are indebted to B. Barnes for sharing his insights into the biology of northern wood frogs. The authors thank D. Larson, M. Snively, and D. Russell for assisting with the logistical challenges of collecting frogs in Alaska. A. Reynolds provided technical assistance and T. Muir contributed with constructive comments on the paper. The project was funded by the National Science Foundation Grant IOS 1022788 to Jon P. Costanzo and the Portuguese Science and Technology Foundation (Fundação para a Ciência e Tecnologia, Ministério da Educação e Ciência, Portugal) Grant SFRH/BD/63151/2009 to M. Clara F. do Amaral. All work reported herein was conducted with the approval of the Institutional Animal Care and Use Committee of Miami University (Protocol no. 812) and permits issued by the Alaskan Department of Fish and Game and the Ohio Division of Wildlife.

\section{References}

[1] M. R. Michaud and D. L. Denlinger, "Genomics, proteomics and metabolomics: finding the other players in insect coldtolerance," in Low Temperature Biology of Insects, D. L. Denlinger and R. E. Lee, Eds., pp. 91-115, Cambridge University Press, New York, NY USA, 2010.

[2] J. P. Costanzo and R. E. Lee, "Commentary: avoidance and tolerance of freezing in ectothermic vertebrates," Journal of Experimental Biology, vol. 216, no. 11, pp. 1961-1967, 2013.

[3] K. B. Storey and J. M. Storey, "Freeze tolerance in animals," Physiological Reviews, vol. 68, no. 1, pp. 27-84, 1988.

[4] K. B. Storey and J. M. Storey, "Persistence of freeze tolerance in terrestrially hibernating frogs after spring emergence," Copeia, vol. 1987, no. 3, pp. 720-726, 1987.

[5] T. A. Churchill and K. B. Storey, "Dehydration tolerance in wood frogs: a new perspective on development of amphibian freeze tolerance," American Journal of Physiology-Regulatory Integrative and Comparative Physiology, vol. 265, no. 6, pp. R1324-R1332, 1993.

[6] J. R. Layne, R. E. Lee, and M. M. Cutwa, "Post-hibernation excretion of glucose in urine of the freeze tolerant frog Rana sylvatica," Journal of Herpetology, vol. 30, no. 1, pp. 85-87, 1996.

[7] J. R. Layne, "Seasonal variation in the cryobiology of Rana sylvatica from Pennsylvania," Journal of Thermal Biology, vol. 20, no. 4, pp. 349-353, 1995.

[8] J. L. Jenkins and D. L. Swanson, "Liver glycogen, glucose mobilization and freezing survival in chorus frogs, Pseudacris triseriata," Journal of Thermal Biology, vol. 30, no. 6, pp. 485494, 2005.

[9] J. P. Costanzo and R. E. Lee, "Cryoprotection by urea in a terrestrially hibernating frog," Journal of Experimental Biology, vol. 208, no. 21, pp. 4079-4089, 2005.

[10] J. P. Costanzo, M. C. do Amaral, A. J. Rosendale, and R. E. Lee, "Hibernation physiology, freezing adaptation and extreme freeze tolerance in a northern population of wood frog," Journal of Experimental Biology, vol. 216, no. 18, pp. 3461-3473, 2013.

[11] D. L. MacArthur and J. W. T. Dandy, "Physiological aspects of overwintering in the boreal chorus frog (Pseudacris triseriata maculata)," Comparative Biochemistry and Physiology A: Physiology, vol. 72, no. 1, pp. 137-141, 1982.

[12] T. J. Muir, J. P. Costanzo, and R. E. Lee, "Metabolic depression induced by urea in organs of the wood frog, Rana sylvatica: effects of season and temperature," Journal of Experimental Zoology A: Ecological Genetics and Physiology, vol. 309, no. 2, pp. 111-116, 2008.

[13] M. P. Kirton, Fall movements and hibernation of the wood frog, Rana sylvatica, in interior Alaska [M.S. thesis], University of Alaska, Fairbanks, Alaska, USA, 1974.

[14] B. Waldman, "Adaptive significance of communal oviposition in wood frogs (Rana sylvatica)," Behavioral Ecology and Sociobiology, vol. 10, no. 3, pp. 169-174, 1982.

[15] R. D. Howard, "Mating behaviour and mating success in woodfrogs Rana sylvatica," Animal Behaviour, vol. 28, no. 3, pp. 705-716, 1980.

[16] N. J. Hudson and C. E. Franklin, "Maintaining muscle mass during extended disuse: aestivating frogs as a model species," Journal of Experimental Biology, vol. 205, no. 15, pp. 2297-2303, 2002.

[17] B. J. Sinclair, J. R. Stinziano, C. M. Williams, H. A. MacMillan, K. E. Marshall, and K. B. Storey, "Real-time measurement of 
metabolic rate during freezing and thawing of the wood frog, Rana sylvatica: implications for overwinter energy use," Journal of Experimental Biology, vol. 216, no. 2, pp. 292-302, 2013.

[18] E. S. Farrar and R. K. Dupre, "The role of diet in glycogen storage by juvenile bullfrogs prior to overwintering," Comparative Biochemistry and Physiology A: Physiology, vol. 75, no. 2, pp. 255-260, 1983.

[19] P. Koskela and S. Pasanen, "Effect of thermal acclimation on seasonal liver and muscle glycogen content in the common frog, Rana temporaria L," Comparative Biochemistry and Physiology A, vol. 50, no. 4, pp. 723-727, 1975.

[20] N. S. Loumbourdis and P. Kyriakopoulou-Sklavounou, "Reproductive and lipid cycles in the male frog Rana ridibunda in Northern Greece," Comparative Biochemistry and Physiology A: Physiology, vol. 99, no. 4, pp. 577-583, 1991.

[21] M. L. Morton, "Seasonal changes in total body lipid and liver weight in the Yosemite toad," Copeia, vol. 1981, no. 1, pp. 234$238,1981$.

[22] K. D. Wells and C. R. Bevier, "Contrasting patterns of energy substrate use in two species of frogs that breed in cold weather," Herpetologica, vol. 53, no. 1, pp. 70-80, 1997.

[23] S. C. Dinsmore II and D. L. Swanson, "Temporal patterns of tissue glycogen, glucose, and glycogen phosphorylase activity prior to hibernation in freeze-tolerant chorus frogs, Pseudacris triseriata," Canadian Journal of Zoology, vol. 86, no. 10, pp. 10951100, 2008.

[24] A. W. Pinder, K. B. Storey, and G. R. Ultsch, "Estivation and hibernation," in Environmental Physiology of the Amphibians, M. E. Feder and W. W. Burggren, Eds., pp. 250-274, The University of Chicago Press, Chicago, Ill, USA, 1992.

[25] K. B. Storey, "Freeze tolerance in the frog, Rana sylvatica," Experientia, vol. 40, no. 11, pp. 1261-1262, 1984.

[26] J. P. Costanzo, M. C. do Amaral, A. R. Rosendale, and R. E. Lee, "Seasonal dynamics and influence of hibernaculum temperature on energy reserves in the wood frog, Rana sylvatica," meeting abstract in Society of Integrative and Comparative Biology, Charleston, SC, USA, 2012.

[27] J. R. Layne and R. E. Lee, "Seasonal variation in freeze tolerance and ice content of the tree frog Hyla versicolor," Journal of Experimental Zoology, vol. 249, no. 2, pp. 133-137, 1989.

[28] W. D. Schmid, "Survival of frogs in low temperature," Science, vol. 215 , no. 4533 , pp. 697-698, 1982.

[29] J. R. Layne, "Freeze tolerance and cryoprotectant mobilization in the gray treefrog (Hyla versicolor)," Journal of Experimental Zoology, vol. 283, no. 3, pp. 221-225, 1999.

[30] J. P. Costanzo, R. E. Lee, and P. H. Lortz, "Glucose concentration regulates freeze tolerance in the wood frog Rana sylvatica," Journal of Experimental Biology, vol. 181, pp. 245-255, 1993.

[31] K. B. Storey, J. G. Baust, and P. Buescher, "Determination of water "bound" by soluble subcellular components during lowtemperature acclimation in the gall fly larva, Eurosta solidagensis," Cryobiology, vol. 18, no. 3, pp. 315-321, 1981.

[32] J. R. Layne, J. P. Costanzo, and R. E. Lee, "Freeze duration influences postfreeze survival in the frog Rana sylvatica," Journal of Experimental Zoology, vol. 280, no. 2, pp. 197-201, 1998.

[33] P. A. King, M. N. Rosholt, and K. B. Storey, "Seasonal changes in plasma membrane glucose transporters enhance cryoprotectant distribution in the freeze-tolerant wood frog," Canadian Journal of Zoology, vol. 73, no. 1, pp. 1-9, 1995.
[34] J. P. Costanzo, J. T. Irwin, and R. E. Lee, "Freezing impairment of male reproductive behaviors of the freeze-tolerant wood frog, Rana sylvatica," Physiological Zoology, vol. 70, no. 2, pp. 158-166, 1997.

[35] E. L. Russell and K. B. Storey, "Glycogen synthetase and the control of cryoprotectant clearance after thawing in the freezetolerant wood frog," Cryo-Letters, vol. 16, no. 5, pp. 263-266, 1995.

[36] Y. Voituron, L. Paaschburg, M. Holmstrup, H. Barré, and H. Ramløv, "Survival and metabolism of Rana arvalis during freezing," Journal of Comparative Physiology B: Biochemical, Systemic, and Environmental Physiology, vol. 179, no. 2, pp. 223230, 2009.

[37] J. R. Layne, "Postfreeze $\mathrm{O}_{2}$ consumption in the wood frog (Rana sylvatica)," Copeia, vol. 2000, no. 3, pp. 879-882, 2000.

[38] J. P. Costanzo, P. A. Callahan, R. E. Lee, and M. F. Wright, "Frogs reabsorb glucose from urinary bladder," Nature, vol. 389, no. 6649, pp. 343-344, 1997.

[39] W. D. Schmid, "Natural variations in nitrogen excretion of amphibians from different habitats," Ecology, vol. 49, no. 1, pp. 180-185, 1968.

[40] S. I. Pisarenko, E. B. Minkovskii, and I. M. Studneva, "Urea synthesis in heart muscle," Bulletin of Experimental Biology and Medicine, vol. 89, no. 2, pp. 138-141, 1980.

[41] J. R. Layne and S. D. Kennedy, "Cellular energetics of frozen wood frogs (Rana sylvatica) revealed via NMR spectroscopy," Journal of Thermal Biology, vol. 27, no. 3, pp. 167-173, 2002.

[42] A. Chakraborty, M. Sarkar, and S. Basak, "Stabilizing effect of low concentrations of urea on reverse micelles," Journal of Colloid and Interface Science, vol. 287, no. 1, pp. 312-317, 2005.

[43] F. O. Costa-Balogh, H. Wennerström, L. Wadsö, and E. Sparr, "How small polar molecules protect membrane systems against osmotic stress: the urea-water-phospholipid system," Journal of Physical Chemistry B, vol. 110, no. 47, pp. 23845-23852, 2006.

[44] X. Wang, W. Lingyun, M. Aouffen, M. Mateescu, R. Nadeau, and R. Wang, "Novel cardiac protective effects of urea: from shark to rat," British Journal of Pharmacology, vol. 128, no. 7, pp. 14771484, 1999.

[45] A. Pollard and R. G. W. Jones, "Enzyme activities in concentrated solutions of glycinebetaine and other solutes," Planta, vol. 144, no. 3, pp. 291-298, 1979.

[46] S. D. Collins, A. L. Allenspach, and R. E. Lee, "Ultrastructural effects of lethal freezing on brain, muscle and malpighian tubules from freeze-tolerant larvae of the gall fly, Eurosta solidaginis," Journal of Insect Physiology, vol. 43, no. 1, pp. 3945, 1997.

[47] J. P. Costanzo, A. L. Allenspach, and R. E. Lee, "Electrophysiological and ultrastructural correlates of cryoinjury in sciatic nerve of the freeze-tolerant wood frog, Rana sylvatica," Journal of Comparative Physiology B: Biochemical, Systemic, and Environmental Physiology, vol. 169, no. 4-5, pp. 351-359, 1999.

[48] M. Hermes-Lima and T. Zenteno-Savín, "Animal response to drastic changes in oxygen availability and physiological oxidative stress," Comparative Biochemistry and Physiology C: Toxicology and Pharmacology, vol. 133, no. 4, pp. 537-556, 2002.

[49] J. Christiansen and D. Penney, "Anaerobic glycolysis and lactic acid accumulation in cold submerged Rana pipiens," Journal of Comparative Physiology, vol. 87, no. 3, pp. 237-245, 1973.

[50] T. V. Bagnyukova, K. B. Storey, and V. I. Lushchak, "Induction of oxidative stress in Rana ridibunda during recovery from winter hibernation," Journal of Thermal Biology, vol. 28, no. 1, pp. 21-28, 2003. 
[51] A. J. Clark, R. Gaddie, and C. P. Stewart, "The anaerobic activity of the frog's heart," The Journal of Physiology, vol. 75, no. 3, pp. 321-331, 1932.

[52] D. G. Penney, "Frogs and turtles: different ectotherm overwintering strategies," Comparative Biochemistry and Physiology A: Physiology, vol. 86, no. 4, pp. 609-615, 1987.

[53] P. L. Rocha and L. G. S. Branco, "Seasonal changes in the cardiovascular, respiratory and metabolic responses to temperature and hypoxia in the bullfrog Rana catesbeiana," Journal of Experimental Biology, vol. 201, no. 5, pp. 761-768, 1998.

[54] T. A. G. Rittenhouse, R. D. Semlitsch, and F. R. Thompson, "Survival costs associated with wood frog breeding migrations: effects of timber harvest and drought," Ecology, vol. 90, no. 6, pp. 1620-1630, 2009.

[55] B. Kessel, "Breeding dates of Rana sylvatica at College, Alaska," Ecology, vol. 46, no. 1-2, pp. 206-208, 1965. 

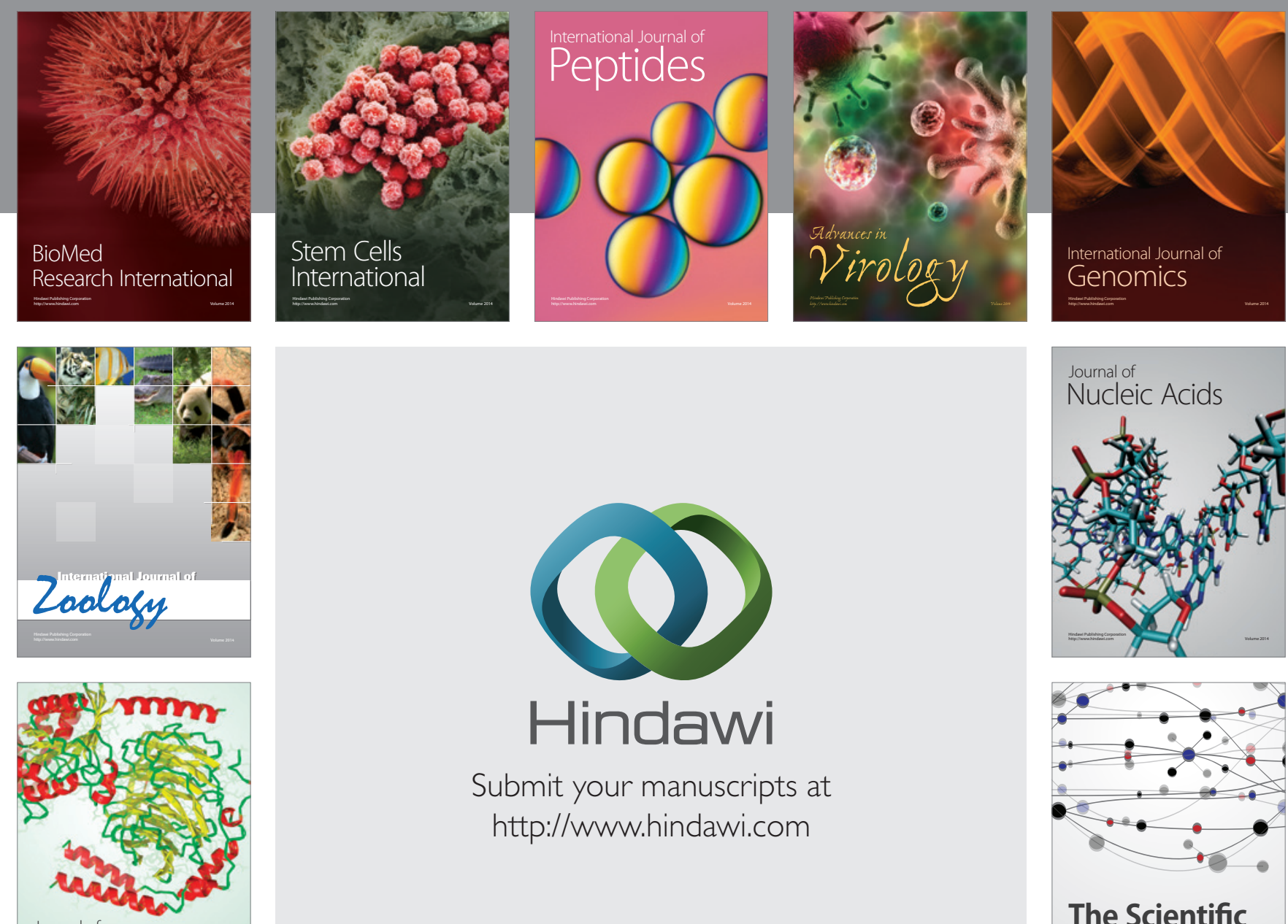

Submit your manuscripts at

http://www.hindawi.com

Journal of
Signal Transduction
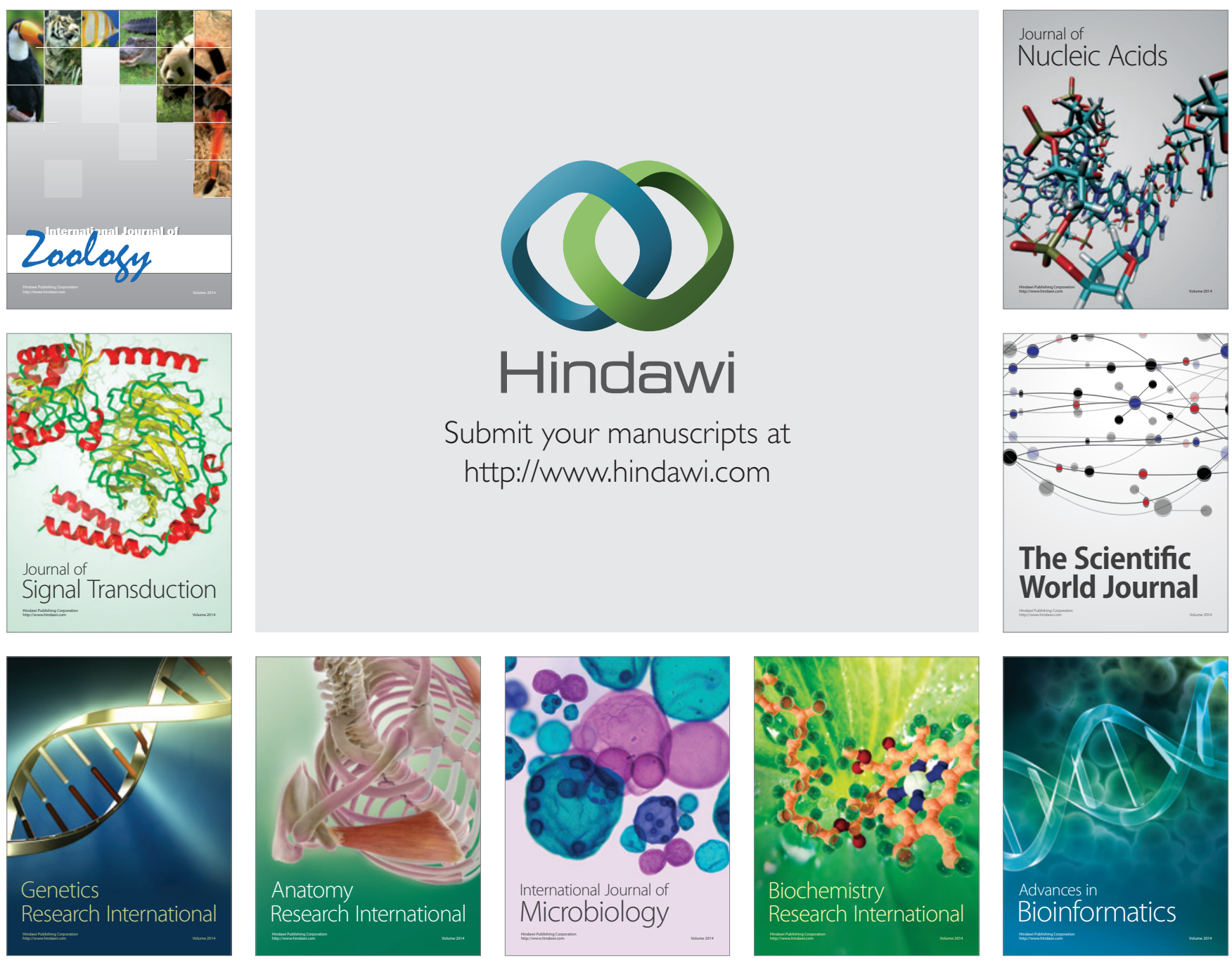

The Scientific World Journal
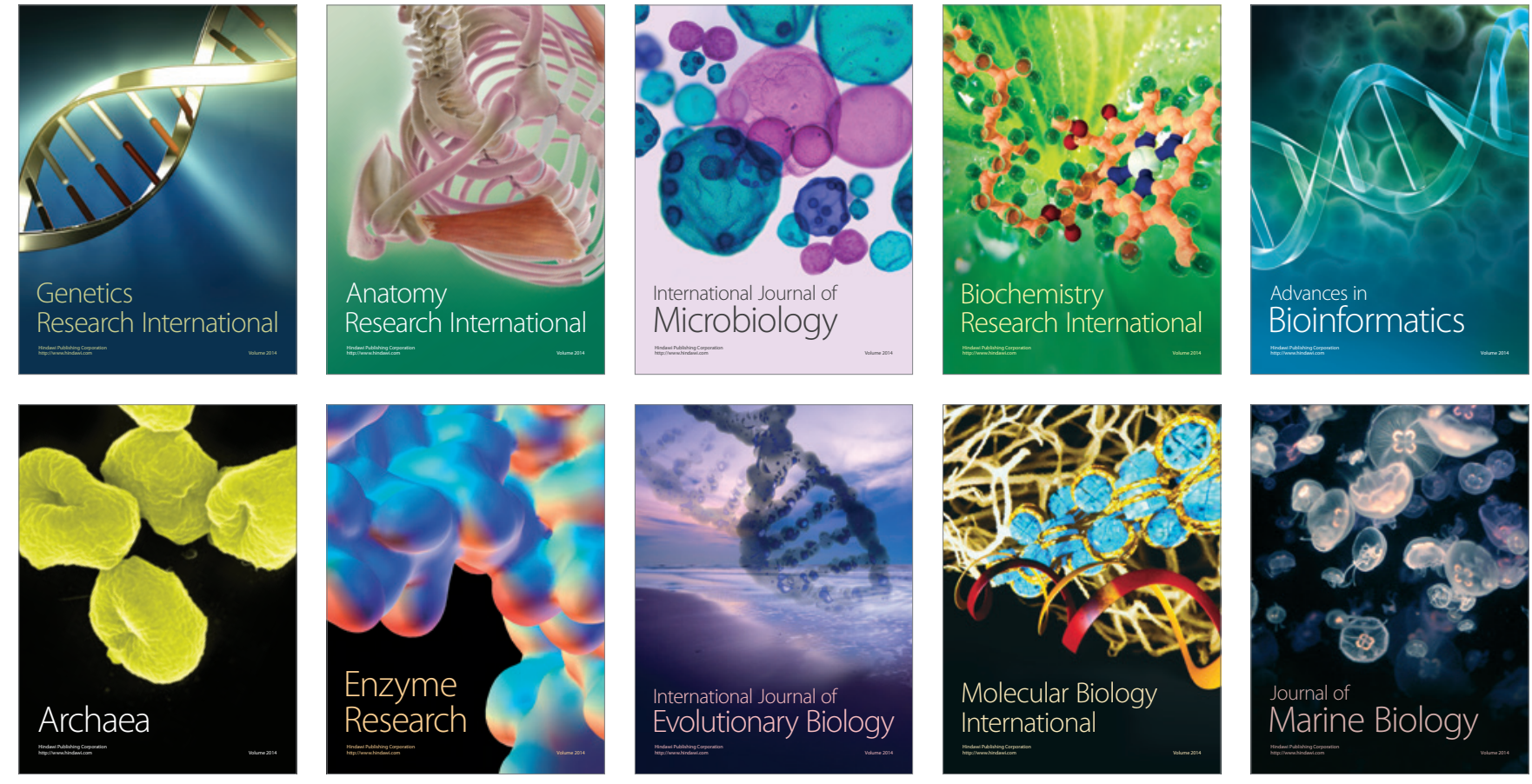